International Journal of Language Education

Volume 5, Number 2, 2021, pp. 63-73

ISSN: 2548-8457 (Print) 2548-8465 (Online)

Doi: https://doi.org/10.26858/ijole.v5i2.15241

\title{
Teachers' Perceptions about the Use of Authentic Material in Pakistani EFL Classrooms
}

\author{
Atiya Rehman \\ University of Lahore, Pakistan \\ Email: atiyadabest@gmail.com \\ Ayesha Perveen \\ Virtual University of Pakistan, Pakistan \\ Email: ayesha@vu.edu.pk
}

Received: 03 October 2020

Reviewed: 12 December 2020-3 February 2021

Accepted: 4 April 2021

\begin{abstract}
This study explores the perceptions of secondary school teachers about the use authentic material in Pakistani English language classrooms. For this quantitative study, data was collected through a survey questionnaire. The questionnaire was adapted from Yeung Ting-fai (2011) and was modified according to the needs of Pakistani educational system. A total of 40 Pakistani secondary school English language teachers responded to the survey questionnaire. Descriptive statistics were used to interpret the data. The results of the study show that most of the teachers liked using authentic material in their classes but were reluctant to do so because of the constraints created by curriculum, examination system and administrative pressures. The study recommends adapting the curriculum and examination systems to facilitate Pakistani secondary school teachers for using authentic material in English language classrooms.
\end{abstract}

Keywords: perception, AMs, secondary schools teachers, english language, Pakistan

\section{Introduction}

Learning a foreign/second language has always been the need of humanity due to one reason or another. For the past few centuries English has been the most popular language to be learnt as a foreign/second language due to the prestige it gained as an international language for communication be it business or academia. When a second language has to be learnt, its teaching also flourishes. Due to the expanding circle of English language, its teaching methodologies and techniques have been widely researched around the world. Besides the academic usages of a second language, there has been a search for methods and techniques to communicate in the second or foreign language in real life situations. This poses a challenge for language instructors who are mostly limited to their classrooms. To address this challenge, the use of authentic material (henceforth AM) came to the fore. According to MacDonald, Badger and Dasli (2006), if there is a communication between the texts used in the classroom and types of texts used outside the classroom then it is imaginable to call such texts authentic. AM refers to the use of materials that 
are otherwise used in communicative language or real-life situations, like newspapers texts, audio conversation or video coverage of real life communication.

From 1970s onwards scholars have emphasized a lot on using AMs in an English language class. According to Kilickaya (2004), it is important that English presented in the classroom should enrich students' learning process and be authentic. Now-a-days using AMs in class and especially in an English language class is a common practice around the world (Nuttall, 1996). There are various types of AMs, for example, realias, printed texts, different types of images i.e. photograph, posters and multimedia, which comprise of video tapes, CD's, DVD's, video clips etc. These can be exciting and encouraging if teachers know how to use these in class.

In a country like Pakistan, English is not just a second language but is an official language as well. Therefore, the pressure of being skilled in English language is enormous on Pakistani students. Although, Urdu enjoys the status of the national language of Pakistan, English always enjoyed equal prestige due to a colonial background. Even in the educational sector, the medium of instruction is English. Therefore, teaching of English in Pakistan is also in need of innovative best practices.

Numerous scholars are of the view that if anyone is desperately eager to use English as their language, he must be wide-open to the language at ease by using it, in his routine life, like all the native speakers do. This purpose has fully boosted with the help of realistic materials used in an English language classroom. The ELT best practices have also placed much concentration on using AM in English language classrooms and it is a common practice in many countries. But at Secondary level in Pakistan, this is not the case as inclusion of AM in the classroom still requires clear policy as well as implementation. However, in this situation it is important to understand teachers' feelings about the use of AM in the classroom. Therefore, the objective of this research is to explore secondary school teacher's perceptions about AM as part of their teaching in English Language classroom. The following research questions have been addressed by the study:

RQ1: What are the perceptions of secondary school teachers about using AM in their classrooms?

RQ: What challenges do secondary school teachers face for using AM in their classrooms?

\section{Literature review}

AM refers to the tools, which are usually involved in language or vocabulary learning for example, real newspaper reports, for example, genuine magazine articles, real advertisements, cooking recipes, horoscopes, audio or videos reflecting real life (Warschauer, 2010). The definitions of AM are slightly different in different types of literature. The common factor among all definitions is its 'realness', its association with the real language and above all its daily use in that community.

Harmer (1991) explained authentic texts as materials which are well-thought-out for intrinsic speakers; linked strongly to the native speakers rather than for the language speakers. Jordan (1997) used AM to refer to transcripts which are not engraved for language teaching tenacities. AM are substantial since it helps in building students' inspiration for learning, expose the learners to the 'real' language (Guariento \& Morley, 2001). The main benefits of using AM include an optimistic result on beginner enthusiasm, deliver authentic ethnic proof, compromise acquaintance to genuine language, narrate additional diligence to students' desires and support a supplementary ingenious tactics to teaching (Richards, 2001). 
Bacon and Finneman (1990, p. 495), stated that teachers must "discover ways and means of manipulating AMs in classroom guidelines." Nunan (1989) provided the conservative definition of AM, for example, the use of print materials like newspapers and timetables, or spoken constituents like public announcements. He further explained that the continuous usage of AM results in better awareness and diversity in the field of learningMany researchers are in favor of AMs to be used in classrooms as they inform students about happenings and trends going around, so they remain up-to-date beside all the educational ethics. (Guariento and Morley, 2001; Paltridge, 2001). According to researchers, these types of materials develop interest and inclination in students learning vocabulary. For example, Thanajaro (2000) noticed that self-righteousness and enthusiasm showed improvement in learners when they used AM for teaching purposes. AM helps in encouraging students to learn the language by providing them genuine use of language (Guariento \& Morely, 2001). Hyland (2003) stated that one of the most significant advantages of using AMs is that it increases learners' motivation and redirects positively to the learning process.

According to McGrath (2002) there are eight standards, which should always be considered, while choosing AMs. These include significance to course books and students' desires, element of curiosity, social fitness, logistical debates, sensitive difficulties, language anxieties, cost, and exploitability. There are three criteria to choose and access texts to be used in the classroom: "suitability of the content, exploitability and readability" (Nuttal, 1996).

Morrow (1977) described an authentic text in a dynamic way by explaining it as the language twisted by a real orator for a genuine audience, so that it can give predictable real messages. Jordan (1997) further explained that it is any material which aids in delivering real content. For Harmer (1991) also AM basically, refers to the texts designed for learners, to attain the maximum of knowledge from foreign language. Lee (1995) reflected authenticity in texts, that it is not necessary that authentic text is developed only for teaching purposes, but it may be used anywhere for communication. However, throughout the antiquity of English language teaching, according to Tatsuk (2006), authenticity is synonymous with realness, authenticity, honesty, soundness, reliability, undisputed believability, and validity of materials or practices. MacDonald, Badger and Dasli (2006) are of the view that if there is a communication between the texts used in the classroom and types of texts used outside the classroom then it is imaginable to call such texts authentic.

Additionally, Mishan (2005) preferred to set some principles for authenticity rather than describing the term. According to her, authenticity is a factor of the attribution and authorship of the text, unique communicative and socio-cultural purpose of the text, original background (e. $\mathrm{g}$. its source, socio-cultural context) of the text and learning activity provoked by the text.

Cooper (1983) defined authenticity as having two different meanings. One refers to the realness and other to communicative connection (Mentioned in MacDonald, Badger and Dasli (2006). MacDonald, Badger and Dasli (2006) classified four types of authenticity: authenticity of text, validity of capability, student validity, and validity of classroom. Lee (1995) pointed out that another kind of authenticity is shaped by the interaction between the user and his purpose, the situation in which the text is being used, and the text sample. Learner authenticity is an important factor of authenticity. Lee outlined it as the students' reactions and their interest and enthusiasm towards real material and the intentions innate in them. The reason why learners will like the materials is not their authenticity every time, but also the communicative property is considered by them.

In Pakistan, it is surprising that many of the teachers use only textbooks for teaching. This may not achieve the applied purpose of reading and understanding. Furthermore, the tasks given 
to students are teacher-centered and students only listen to their teachers. So, their speaking ability is affected to great magnitude as explained by Cheung (2001). These practices are unlikely to lead students to develop an interest in learning English (Bandura, 1986). Students undersupplied by motivation, to acquire a language, want variation and enthusiasm. We must aid them to notice that learning a language is not just learning its structural rules, terminology items etc., but also to have the ability to speak it in an inclusive range (Bell, 2005).

English language is taught in all secondary schools of Pakistan using only textbooks. These textbooks guide the teachers what to teach, while remaining in the same circle. On the other hand, the students lack good English communicative skills although they have great potential to learn. The target of the classroom instruction remains the textual knowledge and innovation is mostly non-existent.

Textbooks syllabus and board paper pattern are not fully aligned with curriculum. The texts included in the textbook do not relate to the instant situations of learners. Secondly, the language or themes of the certain texts might be above or below the learners' level which means that the teaching and learning policies need to allow learners to discover the material at a level suitable to their learning needs (Asghar, 2013). Text books prescribed for grade 9 and 10 over burden the students and encourge rote learning. Learning through these books makes students passive learners. Warsi (2004) has pointed out that textbooks are designed without considering the developmental level of learners. These books are not geared in the direction of accomplishing the verbal requirements of students. English language text books in Pakistan have failed to develop interest and intellectual curiosity in students. In text books, the chief perceptions are indistinct, opinions suffer lack of logic, descriptions are missing, drill are encouraged (Nayyar and Salim, 2005). In this state of affair, the use of AM can play a vital role. In this debate one must not forget about a very important factor which is assessment. Assessment is an integral part education. Valuation is the methodical assortment, evaluation, and usage of data about educational programs supposed for the purpose of improving student learning and development. (Marchese, 1987). Two notorious forms of valuation are summative and formative assessments. Though both mutually play an important role but formative assessment is broader in its perspectives and AM can be used for formative assessments.

\section{Methodology}

This study aimed at exploring the Pakistani secondary school teachers' perceptions about the usage of AMs in second language classrooms. For this purpose a quantitative research design was selected. The population of the study was private schools teachers teaching grade 9 and 10 in the city of Lahore. Data was collected through a survey questionnaire. A total of 40 teachers responded to the survey through informed consent.

The questionnaire used for this study was initially adapted from a research done in Hong Kong by Yeung Ting-fai (2011), entitled "English Language Teachers' Attitudes Towards the use of AMs in Hong Kong Secondary Schools". It was modified to a larger extent according to the context of Pakistani educational system. The questionnaire consisted of three sections consisting of a total of 19 items:

1. The Role of AMs in Language Teaching (4 items)

2. The Contrast Between Local English Textbooks and AMs (6 items)

3. Selection of AM (9 items)

The validity and reliability of the questionnaire was also analyzed. The Table 1.1 given below shows the reliability of the questionnaire. 
Table 1. Cronbach $\alpha$ Reliability coefficients of six parts of the questionnaire regarding perception and attitudes.

\begin{tabular}{llc}
\hline & Items & $\begin{array}{l}\text { Cronbach } \\
\text { Reliability }\end{array}$ \\
\hline The Role of AMs in Language Teaching & 1,2, & 0.70 \\
The Contrast Between Local English Textbooks and AMs & r3,4 & 0.71 \\
Selection of AM & $, \mathrm{r} 9,10$ & 0.82 \\
& $20-28$ & \\
\hline
\end{tabular}

It is very important to see whether your scale is reliable or not. Cronbach $\alpha$ reliability assesses the internal consistency of the scale. Internal consistency means how many items 'hang together' in a scale. Ideally the value of Cronbach $\alpha$ should be higher than 0.7 (DeVellis, 2003). Items related to different aspects of AM have reliability varying from 0.70 to 0.82

\section{Results}

The emphasis of the questionnaire was to gather secondary school teachers' perceptions about the actual use of AMs, to impart vocabulary, at class level 9 and 10. The questionnaire was analyzed through SPSS and results are presented below.

The following table deals with the role of AM in teaching of English language. Four questions were asked. Percentages, means and SDs of responses are presented in the table.

Table 2. Role of AMs in Pakistani Secondary Schools for Language Teaching

\begin{tabular}{|c|c|c|c|c|c|c|c|c|}
\hline $\begin{array}{l}\mathrm{Sr} \\
\text { \# }\end{array}$ & & $\begin{array}{l}\text { SDA } \\
(\%)\end{array}$ & $\begin{array}{l}\mathrm{DA} \\
(\%)\end{array}$ & $\begin{array}{l}\mathrm{N} \\
\%)\end{array}$ & $\begin{array}{l}\mathrm{A} \\
(\%)\end{array}$ & $\begin{array}{l}\text { SA } \\
(\%)\end{array}$ & $M$ & $S D$ \\
\hline 1 & $\begin{array}{l}\text { Compared with local English textbooks, AM } \\
\text { is more beneficial to students' English } \\
\text { learning. }\end{array}$ & 2.5 & 2.5 & 20.0 & 42.5 & 32.5 & 4.00 & 0.93 \\
\hline 2 & AM acts as a supplement to local textbooks. & 0 & 2.5 & 12.5 & 50.0 & 35.0 & 4.18 & 0.75 \\
\hline 3 & $\begin{array}{l}\text { Students can learn English well without } \\
\text { exposure to AM. }\end{array}$ & 0 & $\begin{array}{l}12 . \\
5\end{array}$ & 42.5 & 37.5 & 7.5 & 3.40 & 0.81 \\
\hline 4 & $\begin{array}{l}\text { Students should not be denied the } \\
\text { opportunity to interact with AM. }\end{array}$ & 0 & 0 & 2.5 & 17.5 & 80.0 & 4.78 & 0.48 \\
\hline
\end{tabular}

Note: SDA=strongly disagree, $\mathrm{DA}=$ disagree, $\mathrm{N}=$ Neutral, $\mathrm{SA}=$ strongly agree, $\mathrm{M}=\mathrm{Mean}, \mathrm{SD}=$ standard deviation

$75 \%$ respondents agreed that as compared to local English textbooks, AM was more valuable to students' English learning whereas (5\%) disagreed. 85\% respondents agreed that AM should act as a supplement to local textbooks whereas (2.5\%) were disagreed. A total of $45 \%$ respondents, when asked if students could still learn English well without exposure to authentic texts were positive, however, $12.5 \%$ showed negative response whereas, $42.5 \%$ stayed neutral. The item 'students should not be denied the opportunity to interact with AM' got $97.5 \%$ positive response while $2.5 \%$ respondents remained neutral.

Table 3 presents the contrast between local English text books and AMs. Percentages, means and SDs of responses are presented in the given table. 
Table 3. Contrast between Local English Textbooks and AM

\begin{tabular}{|c|c|c|c|c|c|c|c|c|}
\hline & & $\begin{array}{l}\text { SDA } \\
(\%)\end{array}$ & $\begin{array}{l}\mathrm{DA} \\
(\%)\end{array}$ & $\begin{array}{l}\mathrm{N} \\
(\%)\end{array}$ & $\begin{array}{l}\mathrm{A} \\
(\%)\end{array}$ & $\begin{array}{l}\text { SA } \\
(\%)\end{array}$ & $M$ & $S D$ \\
\hline 1 & $\begin{array}{l}\text { Using AM is always more challenging than } \\
\text { local textbooks. }\end{array}$ & 0 & 5.0 & 17.5 & 37.5 & 40.0 & 4.13 & 0.88 \\
\hline 2 & $\begin{array}{l}\text { Local textbooks are generally lacking in natural } \\
\text { use of English. }\end{array}$ & 0 & 2.5 & 2.5 & 37.5 & 57.5 & 4.50 & 0.68 \\
\hline 3 & $\begin{array}{l}\text { In terms of vocabulary, teaching local } \\
\text { textbooks is more effective than authentic texts. }\end{array}$ & 0 & $\begin{array}{l}12 . \\
5\end{array}$ & 47.5 & 30.0 & 5.0 & 2.43 & 0.96 \\
\hline 4 & $\begin{array}{l}\text { Use of AM for vocabulary learning will } \\
\text { increase the word bank. }\end{array}$ & 0 & 0 & 2.5 & 35.0 & 62.5 & 4.60 & 0.55 \\
\hline 5 & $\begin{array}{l}\text { Activities given in the end of each chapter of } \\
\text { textbook supports the use of AM }\end{array}$ & 0 & 5.0 & 5.0 & 42.5 & 40.0 & 3.40 & 0.90 \\
\hline 6 & $\begin{array}{l}\text { Local textbooks often ignore the cultural } \\
\text { aspects of a language. }\end{array}$ & 0 & 0 & 7.5 & 42.5 & 50.0 & 4.43 & 0.64 \\
\hline
\end{tabular}

Note: $\mathrm{SDA}=$ strongly disagree, $\mathrm{DA}=$ disagree, $\mathrm{N}=$ Neutral, $\mathrm{SA}=$ strongly agree, $\mathrm{M}=\mathrm{Mean}, \mathrm{SD}=\mathrm{standard}$ deviation

Among all respondents $77.5 \%$ agreed and strongly agreed that using AM is more challenging than local textbooks whereas $17.5 \%$ were neutral. A total of $95 \%$ respondents agreed and strongly agreed that local textbooks do lack in natural use of English whereas $2.5 \%$ were neutral. The item 'use of AM for vocabulary learning will increase the word bank' received 97.5\% positive response while $2.5 \%$ were neutral. Item 'Activities given at the end of each chapter of support the use of AM' got $82.5 \%$ positive responses with $5 \%$ disagreement. The item 'local textbooks often ignore the cultural aspects of a language' got $92.5 \%$ positive response.

Table 4 presents responses of teachers about the selection of AM for their classroom. Percentages, means and SDs of responses are presented in the table given below (see Table 4).

Table 4. Selection of AM

\begin{tabular}{|c|c|c|c|c|c|c|c|c|}
\hline & & $\begin{array}{l}\text { SDA } \\
(\%)\end{array}$ & $\begin{array}{l}\mathrm{DA} \\
(\%)\end{array}$ & $\begin{array}{l}\mathrm{N} \\
(\%)\end{array}$ & $\begin{array}{l}\text { A } \\
(\%)\end{array}$ & $\begin{array}{l}\text { SA } \\
(\%)\end{array}$ & $M$ & $S D$ \\
\hline 1 & $\begin{array}{l}\text { When selecting texts, the length of the material is } \\
\text { your prime consideration }\end{array}$ & 7.5 & 5.0 & 12.5 & 62.5 & 12.5 & 3.68 & 1.02 \\
\hline 2 & $\begin{array}{l}\text { Selecting AM which is suitable for students' } \\
\text { English level is time-consuming. }\end{array}$ & 2.5 & 7.5 & 12.5 & 62.5 & 15.0 & 3.80 & 0.88 \\
\hline 3 & $\begin{array}{l}\text { It is difficult to manage time in class while using } \\
\text { AM incorporation to other class activities. }\end{array}$ & 5.0 & 32.5 & 7.5 & 42.5 & 12.5 & 3.25 & 1.19 \\
\hline 4 & $\begin{array}{l}\text { It is difficult to complete the syllabus while using } \\
\text { AM in class }\end{array}$ & 22.5 & 42.5 & 10.0 & 12.5 & 12.5 & 2.50 & 1.32 \\
\hline 5 & $\begin{array}{l}\text { It is difficult to find material that matches the } \\
\text { content of the school curriculum. }\end{array}$ & 0 & 25.0 & 35.0 & 35.0 & 5.0 & 3.20 & 0.88 \\
\hline 6 & $\begin{array}{l}\text { It is difficult to find materials that match the } \\
\text { content of Textbooks. }\end{array}$ & 5.0 & 40.0 & 17.5 & 30.0 & 7.5 & 2.95 & 1.11 \\
\hline 7 & $\begin{array}{l}\text { It is difficult to find materials that are relevant to } \\
\text { students' lives and interests. }\end{array}$ & 5.0 & 37.5 & 25.0 & 25.0 & 7.5 & 2.93 & 1.07 \\
\hline 8 & $\begin{array}{l}\text { It is difficult to develop AM according to your } \\
\text { needs? }\end{array}$ & 7.5 & 52.5 & 15.0 & 22.5 & 2.5 & 2.60 & 1.01 \\
\hline 9 & $\begin{array}{l}\text { It is difficult to find relevant material to teach } \\
\text { vocabulary. }\end{array}$ & 5.0 & 50.0 & 15.0 & 25.0 & 5.0 & 2.75 & 1.06 \\
\hline
\end{tabular}


Note: $\mathrm{SDA}=$ strongly disagree, $\mathrm{DA}=$ disagree, $\mathrm{N}=$ Neutral, $\mathrm{SA}=$ strongly agree, $\mathrm{M}=\mathrm{Mean}, \mathrm{SD}=\mathrm{standard}$ deviation

There were $75 \%$ participants who agree and strongly agreed that the length of the material was prime consideration while selecting texts. There were $77.5 \%$ participants who agreed and strongly agreed that selecting AM which was suitable for students' English level was timeconsuming. Among all the respondents, 55\% strongly/agreed and strongly agreed that it was difficult to manage time in class while using AM whereas $65.5 \%$ strongly/disagreed. Twenty-five percent strongly/agreed that it was problematic to complete the syllabus while using AM in class whereas $65 \%$ strongly/disagreed. Forty Percent supported the argument that it was difficult to find material that matches the content of the school curriculum whereas $25 \%$ strongly/disagreed. It was also observed that $37.5 \%$ strongly/agreed that it was difficult to find material that matches the content of textbooks while $45 \%$ people disagreed. $32.5 \%$ were positive that it was difficult to find materials that were relevant to students' lives and interests while $42.5 \%$ showed negative response. Only $23 \%$ believed that it was difficult to develop AM according to your needs while $60 \%$ showed negative response. It was difficult to find relevant material to teach vocabulary was seen with $30 \%$ positive the result while $55 \%$ disagreed.

\section{Discussion}

The main focus of the study was to explore the perceptions of the secondary school teachers about using use AM in English language classrooms in Pakistan. As shown in the responses to the item of section 1, the secondary school teachers were very positive about the effectiveness of authentic material. They strongly agreed that AM can be more beneficial than prescribed textbooks by the secondary schools. Although textbooks cannot be discarded, AM can be a very good supplement for the prescribed textbooks. Morrow (1977) also claimed that "an authentic text is a text that is the expansion of actual language but shaped by a real speaker or writer for a genuine audience. It is designed to transport a real message of some variety to its reader". Şaraplı (2011) described AM as an effective tool which is used for teaching in the classroom. He was of the view that AM pays more attention to the understanding ability of students rather than the material provided.

Although $42.5 \%$ of the participants were neutral to the item: "students can learn English well without exposure to AM", they were extremely positive (97.5 agreement) that students must not be denied the opportunity to interact with AM. Communicative aspects of language have been usually ignored in lessons and textbooks. In order to have a strong grasp on English vocabulary students must be exposed to AMs in a larger perspective (Gilmore, 2007).

The results of the section 2 of the questionnaire also emphasized the eagerness of the teachers about AM. They were affirmative about the limitations of the textbooks in making students learn in a natural way. This aspect is also highlighted by Gilmore (2007). Although they found teaching through using AM more challenging than through texts (87.5 agreement), they considered AM more effective in general and for teaching vocabulary in particular. Another very important aspect is the relation of culture and language which can be highlighted through the use of AM. 92.7\% teachers agreed that text books ignore the cultural aspect of a language. The textbooks are encompassed with the text, which is discrete to the instant surroundings of learners (Asghar, 2013).

Seventeen teachers stayed neutral when asked if activities given in the end of the textbook supported AM and nineteen agreed to it, showing that they might not be paying attention to this aspect. Thirty-nine out of forty participants agreed to the fact that word bank will increase if AM is used for vocabulary learning. Students who were wide-open to only scripted spoken dialogues 
had less chance to learn their linguistic features which would always be useful for them in formulating new vocabulary for themselves, or for any unexpected social discussions (Burns, 2001).

The third part of the questionnaire focused on the challenges teachers faced while using AM in classrooms. Teachers in private schools of Pakistan are overburdened. Mostly, they have to prepare more than three lessons for each class and have to take 25 to 30 periods per week. This burden is enough to discourage them from being creative. At times, they might not be able to put extra effort due to some personal reasons. Other than that, there is a lot of pressure on the teacher to complete the course in time which may affect their motivation level.

It is a matter of concern for teachers as they have to manage other class activities as well. Teachers also don't want to panic the students, by giving them unwanted extensive material. Thirty-one teachers agreed that selecting AM according to the class level was time consuming. Similarly, twenty-two teachers were of the view that it was difficult to manage time while using AM along with other class activities. It is true, in Pakistani system of education class 9 and 10 are the most pressure ridden classes. Target of the teachers and students both is to accomplish high marks. Although time management becomes difficult, twenty-six teachers think that it is not difficult to complete syllabus while using AM in class. Half of Teachers found it difficult to look for material which coordinated the content of textbooks and approximately for another half it was not difficult. This showed that not all have access to the resources from where AM can be arranged. So in this situation half of the teachers found it difficult to prepare AM according to their use while the rest were either disagreeing to it or are neutral. When asked if it is difficult to find relevant material to teach vocabulary, twenty-two disagreed to it whereas twelve participants agreed. According to Marzano (2006), a lot more is expected from good students in case of vocabulary as they tend to learn quick and rapid. So, the biggest responsibility is on the teacher's shoulders to develop interest in lectures. According to Johnson (2006) there are more economical and quick ways to access sources of finding relevant material these days as compared to the past e.g. T.V, radio, computers, newspapers etc. Change occurs through interaction with new ideas, understandings, and real-life experiences but the teacher still found it difficult to find AM. This could be because finding appropriate AMs is a very time taking task. Furthermore, the continuous pressure on the teachers one of which is to complete the syllabus in time, refrain them from using these strategies effectively.

\section{Conclusion and recommendations}

The study focused on exploring teachers' perception about the use of AM in Pakistani Secondary School classrooms. Although teachers in Pakistani secondary schools are facing a lot of constraints due to curricular and management issues, they are motivated and prefer AM as a supplement resource to be used along with textbooks for teaching English language in the classroom.

Teachers feel that learners need for learning English language through AM is of less importance as their focus is more towards attaining maximum marks rather than learning English language. However, the same teachers are against the notion of keeping students away from using AM. The textbooks lack natural language use and cultural aspects as pointed out by the teachers, due to which books are not quite effective. Therefore, AM can be a very good supplementary resource. 
The results point out that regardless of teachers' motivation and need of content to inculcate AM as supplement to textbook in Pakistani Secondary School classroom for teaching English language, current curriculum and education system does not encourage for bringing up the AM into the classroom. Therefore, it is suggested for curriculum developers to include AM in the English language textbooks to aid broader aim of students' learning. Policy makers can also make possible amendments in the assessment system to allow teachers to bring up activities based on AM to enhance the learning process. Moreover, school management can also take steps to support their teachers for including AM based activities in the classroom. Although, in the present situation it will be a burdensome task but teachers can also adapt such lesson plans which are based on authentic texts and are relevant to the textbooks' content.

Declaration of conflicting interest

The authors state that there is no conflict of interest concerning the publication of this article.

Funding acknowledgement

This research received no external funding.

\section{References}

Asghar, J. (2013). Change for the better: an evaluative study of a textbook. Language, Individual and society., 7(1), $404-$ 422. Retrieved from https://www.researchgate.net/publication/260674996_Change_for_the_Better_An_Evaluati ve Study_of an_English_Textbook

Bacon, S. M. and Finnemann, M. D. (1990). A study of the attitudes, motives, and strategies of University foreign students. Modern Language Journal, 74(4),459-473. https://doi.org/10.1111/j.1540-4781.1990.tb05338.x

Bandura, A. (1986). Social foundations of thought and action: A social cognitive theory. Englewood Cliffs, NJ: Prentice Hall.

Bell, F. L. (2005). Comprehension aids, internet technologies, and the reading of AMs by adult second language learners. PhD dissertation. The Florida State University. Retrieved from https://www.lib.fsu.edu/find/etds.html

Bennett, S., Maton, K. \& Kervin, L. (2008). The 'digital natives' debate: A critical review of the evidence. British Journal of Educational Technology, 39(5), 775-86.

Burns, A. (2001). Analysing Spoken Discourse: Implications for Tesol. In Anne Burns, \& Caroline Coffin (Eds.), Analysing English in a Global Context (pp. 123-148). Routledge, Taylor and Francis Group.

Cheung, C. (2001). The use of popular culture as a stimulus to motivate secondary students' English learning in Hong Kong. ELT Journal., 55(1), 55-61. doi:10.1093/ELT/55.1.55

Cooper, M. (1983). The Role of the Teacher Specialist in the New York City Teacher Center. Urban Educator, 7(1), 49.

DeVellis, R. F. (2003). Scale development: theory and applications. London: Sage Publications

Johnson, C.C. (2006). Effective professional development and change in practice; barriers science teachers encounter and implications for reform. School Science and Mathematics, 106 (3), 150-161. https://doi.org/10.1111/j.1949-8594.2006.tb18172.x

Gilmore, A. (2007). AMs and authenticity in foreign language learning. Language Teaching, 40(2), 97-118. doi:10.1017/S0261444807004144

Guariento, W. and J. Morely. (2001). Text and task authenticity in the EFL classroom. ELT 
Journal, 55 (4), 347-353. doi:10.1093/ELT/55.4.347

Harmer, J. (1991). The Practice of English Language Teaching. New York: Longman. Hyland, K. (2003). Second language writing. Cambridge:Cambridge University Press Jordan, R. (1997). English for Academic Purposes: A Guide and Resource for Teachers. Cambridge: Cambridge University Press.

Kilickaya. F. (2004). AMs and cultural content in EFL classrooms. The Internet TESL Journal, 10 (7). Retrieved from http://iteslj.org/Techniques/Kilickaya AutenticMaterial.html.

Lee, W. (1995). Authenticity revisited: Text authenticity and learner authenticity. ELT Journal., 49(4), 323-328. doi:10.1093/ELT/49.4.323

Leyden, M. B. (1984). You graduate more criminals than scientists. Sci. Teach. 51:27-30.

MacDonald, M. N., Badger, R., \& Dasli, M. (2006). Authenticity, culture and language learning. Language and Intercultural Communication, 6(3-4), 250-261. https://doi.org/10.2167/laic252.0

Marchese, T.J. (1987) Third Down, Ten Years to Go. AAHE Bulletin, 40, 3-8.Retrieved from https://www.scirp.org/(S(oyulxb452alnt1aej1nfow45))/reference/ReferencesPapers.aspx?R eferenceID $=1211360$

Marzano, R. J. (2006). Classroom assessments and grading that work. Alexandria, VA: Association for Supervision and Curriculum Development.

McGrath, I. (2002). Materials evaluation and design for language teaching. Edinburgh: Edinburgh University Press.

Miller, M. (2005). Improving aural comprehension skills in EFL, using authentic materials: an experiment with university students in Nigata, Japan. Unpublished Masteral thesis, University of Surrey, Guildford, UK.

Mishan, F. (2005). Designing Authenticity into Language Learning Materials. Bristol: Intellect books.

Morley, J. (1991). Listening comprehension in foreign language instruction. Boston, USA.

Morley, J. (2001). Aural comprehension instruction: Principles and practices. In Celce- Murcia, M. (Eds.), Teaching English as a second language (pp. 69-85). Boston: Heinle \& Heinle.

Morrow, K. (1977). Authentic texts in ESP. In Holden, S.(Ed). English for specific purposes. London: Modern language publications.

Mousavi, S., A., \& Iravani, H. (2012). The effect of authentic versus non-authentic aural materials on EFL learners ' listening comprehension. English Language and Literature Studies, 2(1), 21-27.

Nation, I. S. P. (2001). Learning Vocabulary in Another Language. Cambridge: Cambridge University Press.

Nayyar, A. H. and Salim, A. (2005). The Subtle Subversion: the State of Curricula and Textbooks in Pakistan. Retrieved from https://www.academia.edu/2585776/The_subtle_subversion_the_state_of_curricula_and_te xtbooks_in_Pakistan_Urdu_English_Social_Studies_and_Civics

Nunan, D. (1989). Designing tasks for the communicative classroom. Cambridge: Cambridge University Press.

Nunan, D. (1989). Designing tasks for the communicative classroom. Cambridge University Press. Nunan, D. (1999). Second language teaching and learning. UK: Heinle \& Heinle publishers.

Nuttall, C. (1996). Teaching reading skills in a foreign language. Oxford: Oxford University Press. Nostrand, H. (1989). Authentic texts and cultural authenticity: An editorial. The Modern Language Journal, 73(1), 49-52. http://dx.doi.org/10.1111/j.1540-4781.1989.tb05310.x 
Otte, J. (2006). Real language to real people: A descriptive and exploratory case study of the outcomes of aural authentic texts on the listening comprehension of adult ESL students enrolled in an advanced ESL listening course. Dissertation Abstracts International, 67(4), 1246B. (UMI No. 3212979)

Paltridge, B. (2001). Genre and the language learning classroom. Michigan: University of Michigan.

Richards, J. C. (2001). Curriculum Development in Language Teaching. Cambridge: Cambridge University Press

Şarapl, O . (2011). The Use of Authentic Materials in The Second Language Classrooms: Advantages and Disadvantages . Dil Dergisi , (154) , 37-43 . doi: 10.1501/Dilder_0000000160

Tatsuki, D. (2006). What is authenticity? The language teacher, 16(5),17-21. Retrieved from https://hosted.jalt.org/pansig/2006/HTML/Tatsuki.htm

Thanajaro, M. (2000). Using AMs to develop listening comprehension in the English as a foreign language classroom. Doctoral dissertation, Virginia Polytechnic Institute and State University, Blacksburg, Virginia.Retrieved from http://hdl.handle.net/10919/26336

Warsi, J. (2004). Conditions under which English is taught in Pakistan: An applied linguistic perspective. Sarid Journal, 1(1), 1-9. Retrieved from https://citeseerx.ist.psu.edu/viewdoc/download?doi=10.1.1.562.9996\&rep=rep1\&type=pdf

Warschauer, M. (2010). Invited commentary: New tools for teaching writing. Language Learning and Technology., 14(1), 3-8. Retrieved from https://citeseerx.ist.psu.edu/viewdoc/download?doi=10.1.1.215.2039\&rep=rep1\&type=pdf

Yeung, T. F. (2011). English language teachers' attitudes towards the use of AMs in Hong Kong secondary schools. Retrieved from https://citeseerx.ist.psu.edu/viewdoc/download?doi=10.1.1.843.3669\&rep=rep1\&type=pdf 